\title{
IDENTITY OF KĀRLIS RŪDOLFS KREICBERGS IN HIS LIFE
}

\author{
Arturs Medveckis \\ Liepaja University Sociological Research Center, Latvia
}

\begin{abstract}
The aim of the paper is to analyse the identity of Latvian pedagogue and conductor Kärlis Rüdolfs Kreicbergs (1921-2014), by using the author's elaborated theoretical model of identity research (2016), and the integrated author's approbated personality research model (2013). The personality research model, which, in its micro context, includes basic features of his personality - emotions, talent, behaviour and convictions, as well as adaptation characteristics - interests, motivations, values, attitudes, is supplemented with components determining the identity of the pedagogue: in mezzo context in the social environment, where the identity of the pedagogue, as well as family, identity in his everyday life, student's and religious identity is formed, but in micro context, - professional, national, local, political and cultural identity of the personality, thus creating a research model of the multidimensional identity of the teacher and factors influencing development thereof. After the approbated model with the help of qualitative research methods the obtained data are related to theoretical opinions about the identity formation of the pedagogue, thus approving the innovative character of the proposed theoretical model.
\end{abstract}

Keywords: identity research model, biographical approach, case study, components of the identity, identity of a pedagogue.

\section{Introduction}

The subheading Biographical insights about the excellent cultural and educational professional - conductor, teacher (Biogräfiska apcere par izcilu kultūras un izglìtības darbinieku - dirigentu, skolotāju) of the author's monograph Kärlis Rüdolfs Kreicbergs and his Life (Kärlis Rüdolfs Kreicbergs un vina laiks) (Medveckis, 2012) includes a statement, which relates to the important questions of the identity. The author, having continuous contact with the person to whom the monograph is dedicated as well as with the people, with whom K.R. Kreicbergs had the tightest relations during his life does not have any doubts regarding the title of the subheading. In the entries included into the Liepaja University (Latvia) Staff Bibliographical Index (Medveckis, 2007), according to formal criteria an approval is obtained for the professional field, but without answers about the work quality. An insight about his view on personal life is obtained from the life story of Kārlis Rūdolfs Kreicbergs (Medveckis, 2004:45-63). His view is a self-reflection and a construct of his own identity (Abrams, 2010). 
Not all the persons - family members of K. R. Kreicbergs, his students, choir members, colleagues -, who described K. R. Kreicbergs, had the same opinion. This created research interest to find approval or to put into question the fairness of the subheading. Biographical research approach (Tompson, 2000; Bela, 2004) is useful for this, as well as the author's elaborated and approbated Theoretical Model of Teachers Identity Research (Medveckis, 2016).

The biographical research approach is used for studying the stage of the pedagogue's identity formation and self-awareness (Knowles, 1992). The main idea of pedagogue's personality is found in the research of Evija Strika (Strika, 2009), and the identity concept comes originally from the theoretical identity concepts of Danish lifelong-education problem researcher Knud Illeris (Illeris, 2014).

The elaborated Theoretical Model of Teachers Identity Research is approbated in the practical research. More information about it can be found in the author's publication (Medveckis, 2015), which was published after IJAS conferences in Prague (2014), Freiburg (2014), but the results of the practical research of the Theoretical Research Model of Pedagogue's Identity and its Influential Factors have been published for the first time.

\section{Theoretical justification}

Personality reflection in relation to cognitions of childhood selfness is analysed in the works of Imants Plotnieks, doctor of Psychology, approving that sense of well-being is an important factor of personal identity formation (Plotnieks, 1998:11). Kristīne Mārtinsone emphasizes the importance of adequate self-assessment in the process of identity study (Mārtinsone, 1998), selfness in the narrative form at the moment of his life-retelling. Interwoven search for new identities is a proper feature of life-stories, which originates from the author's experience in empirical work, where deeper theoretical statements of identity formation are found in the works of British Sociology Professor Richard Jenkins (Jenkins, 2008), however, during life changes in apprehension of selfness are possible, and stability of the identity is not an exclusion as well. Special attention to variety of research and interpretation of selfness and identity transformation processes was given by the Danish lifelong-education problem researcher Knud Illeris, admitting that identity study and self-understanding are not programmed as permanent for all the times (Illeris, 2014).

A sociologist Dagmara Beitnere, describing self-references in the narrative form, refers to opinions of a German sociologist Niklas Luhmann (Luhmann, 1999), linking those to the identity and finds out that according to the system theory self-reference is more important than identity, because identity changes when self-reference changes (Beitnere, 2003.) 
The concept of Knud Illeris includes also the idea of the identity core, which forms the main identity, which is included in the three concentric layers of the main identity, which altogether form the primary or general structure of the identity - personality layer. According to Illeris, personality layer is more flexible, that is more susceptible in relation to changes, acquiring new impressions, facing new circumstances (Illeris, 2014). The author, outlining a preference layer, interprets it as a changeable element of identity, which refers to everyday identity, but links incomplete or partial identity to one or two main fields that can generally be called as relations and our practices, which at the same time show that such incomplete (partial) identities can be connected to each other in different types, in different cultures, different traditions and norms and serve for different groups of people (Illeris, 2014:74-75).

If the previously mentioned identity parts relate to identity as a whole, what is respected by holistic theory representatives, as, for instance, Daina Liegeniece (Lieǵeniece, 1992, 2002, 1999, 1996, 2013), then there is also a cross-sectional structure, which includes various fields of identity or incomplete (partial) identities. Altogether these incomplete (partial) identities are connected and touch upon three main fields: working identity, family identity and everyday identity or interest identity, however, these, taking into account interconnections with the relations, can be divided into three categories, which Illeris called as national cultural identity, religious identity and political identity (Illeris, 2014:75).

Illeris emphasizes that some incomplete (partial) identities, especially in connection with the main identity, are usually tightly connected with the central main identity, and at the same time each one has his own core.

In the author's research MODEL OF TEACHERS' IDENTITY FACTORS IN THE BIOGRAPHICAL RESEARCH, which is published in International Journal of Multidisciplinary (Medveckis, 2015), it is concluded that the most important personality features of the teacher in the field of humanities, which is represented also by Kārlis Rūdolfs Kreicbergs, is the identity, which determined the further research outlines. The model of factors influencing teacher's personality is theoretically grounded and approbated in practical researches, where the next approbation stage is linked with approbation of the Theoretical Research Model of Teachers Identity and Factors Influencing Development thereof.

\section{Methodology}

The full research cycle involves modelling of scientific researches in the field if philosophy, sociology, anthropology, semiotics, pedagogy, psychology, history, cultural studies, which include also study and analysis of historical, 
biographical sources within the supported theories. In the further course of the research methods of empirical data acquisition are used: surveys, interviews, focus groups discussions, gathering of biographical and historical data, generalisation, and systematisation. For data processing interview transcribing, coding, content analysis, historically-logical analysis, the descriptive method is used. In the 3rd stage of the research 64 respondents were involved, to whom respondent codes were assigned within the research.

Table 1 Code system for determination of K. R. Kreicbergs identity and factors influencing development thereof in the life activity of the pedagogue

\begin{tabular}{|c|c|c|c|}
\hline \multirow[t]{2}{*}{ profile codes } & \multirow[t]{2}{*}{ respondent codes } & \multicolumn{2}{|c|}{ contents (conceptual) codes } \\
\hline & & multiple codes & meta codes \\
\hline \multirow[t]{7}{*}{ /krcb_str_int_klg } & \$vikmanis_v & ident_uzsk & \multirow[t]{9}{*}{ pers_asp } \\
\hline & \$racevskis_e & ident_uzv & \\
\hline & \$kronbergs_v & ident_emoc & \\
\hline & \$paipare_m & ident_tal & \\
\hline & \$blauzde_o & ident_int & \\
\hline & \$valce_i & ident_rakst & \\
\hline & \$medveckis_a & ident_vert & \\
\hline \multirow[t]{6}{*}{ /krcb_dz_str_int_gm } & \$sieva & ident_mot & \\
\hline & \$masa & ident_att & \\
\hline & \$meita & ident_ped & \multirow[t]{4}{*}{ soc_asp } \\
\hline & \$dels & ident_stud & \\
\hline & \$vedekla & ident_gim & \\
\hline & \$mazdels & ident_relig & \\
\hline \multirow[t]{4}{*}{ /krbg_fkg_dsk_kr } & \$ rijnieks_o & ident_ikd & \multirow{6}{*}{ kult_vest_asp } \\
\hline & \$valters_a & ident_prof & \\
\hline & \$kirsteins_j & ident_kult & \\
\hline & \$bercis_g & ident_polit & \\
\hline \multirow[t]{7}{*}{ /krcb_dl_str_int_audz } & \$ivanova_a & ident_nac & \\
\hline & \$piraga_m & ident_viet & \\
\hline & \$smiltniece_g & iaif_izV & \multirow[t]{6}{*}{ iaif } \\
\hline & \$dambe_1 & iaif_ldzd & \\
\hline & \$ziemele-kluce_i & iaif_atz & \\
\hline & \$balode_i & iaif_dros & \\
\hline & \$amerika_ansina_1 & iai_uzt & \\
\hline /krcb_gd & gd_1-40 & iaif_jb & \\
\hline
\end{tabular}

According to the strategy of the research, using the theoretical statements as a basis, a code system was elaborated, which is formed by respondents' codes, profile codes, content (conceptual) codes (multiple codes and metacodes) (see Table 1).

To be able to compare opinions of various respondent groups about the identity of K. R. Kreicbergs and the factors of development thereof within the 
socialisation process, as well as to determine the differences between various groups, profile codes were created, grouping the respondents according to the chosen primary data acquisition method: case analysis (/krcb_gd), focus group discussion (/krcb_fkg_dsk_kr), structured interviews (/krcb_str_int_klg), partially structured interviews (/krcb_dl_str_int_audz_st) and deep structured interviews (/krcb_dz_stra_int_gm), thus providing triangulation. Using structured interviews, 7 colleagues of K. R. Kreicbergs were interviewed; using partially structured interviews - 7 pupils and students; using deep structured ones -6 family members, in the focal group discussions 4 choir members took part; using case analysis, 40 cases of K. R. Kreicbergs self-reflection about the identity were analysed.

In the meta code denoting the personality aspect of the identity ,pers_asp” such multiple codes are included as emotional code ,ident_emoc", behaviour code ,ident_uzv”, conviction code ,ident_uzsk”, talent code ,ident_tal”, interests code ,ident_int”, character code ,ident_rakst”, value code ,ident_vert”, attitude code ,ident_att” and motivation code ,ident_mot”.

In the meta code denoting the social aspect of the identity ,soc_asp” such multiple codes are included as pedagogue's identity code ,ident_ped”, student's identity code ,ident_stud”, family identity code ,ident_gim”, religious identity code ,ident_relig" and everyday identity code ,ident_ikd".

In the meta code denoting the cultural and historical aspect of the identity „kult_vest_asp” such multiple codes are included as professional identity code „ident_prof", national identity code ,ident_nac”, location identity code „ident_viet”, political identity code ,ident_polit” and cultural identity code ,ident_kult”.

In the meta code denoting the factors influencing development of the identity ,iaif” such multiple codes are included as choice code ,iaif_izv”, participation code ,iaif_ldzd”, recognition code „iaif_atz”, safety code „iaif_dros”, trust code „,iai_uzt” and moral obligation code „iaif_jb”.

For identification of environment categories such multiple codes were created as work environment code „darb_vide”, study environment code „stud_vide”, family environment code „gim_vide”, community environment code „kop_vide” and everyday environment code ,ikd_vide”, which are united into the meta code denoting micro context "mezo_kont”, as well as the educational environment code „izgl_vide”, ethnical environment code „etn_vide”, geographical environment code ,geogr_vide”, political environment code ,polit_vide” and cultural environment code „kult_vide”, which are united into the meta code denoting macro context „makro_kont”.

In the meta code denoting the factors influencing development of the identity „iaif” such multiple codes are included as choice code ,iaif_izv”, 
participation code ,iaif_lidzd”, recognition code „iaif_atz”, safety code ,iaif_dros”, trust code ,iai_uzt” and moral obligation code „,iaif_jb”.

In the software environment for qualitative data processing "AQUAD" frequency tables are created for determining frequencies of codes denoting pedagogue's personal and professional competencies, linkages between the identity and environment as well as identified pedagogue's identity formation condition conformities (implicants).

For provision of maximal fairness and reliability as well as for generalisation a mixed approach of data processing methods is used - parallel to qualitative methods in the AQUAD software environment quantitative data processing methods are used in SPSS software environment, in order to make sure whether the secondary data acquired with the qualitative methods correspond to and are not contrary to the data acquired by the quantitative methods.

In the SPSS environment data processing involves use of Chi-Square test for determination of differences between the identity as a personality category and the groups of respondents as well as for cluster analysis for identification of respondent groups. As the empirical distribution does not correspond to normal distribution $(\mathrm{p}=0.000)$, non-parametric methods are used - Kendall's tau-b correlation analysis to determine relations (correlations) between categories and Kruskal-Walis $\mathrm{H}$ test to determine differences among 3 independent groups of respondents.

\section{Results of the research}

Complete research of the identity is possible if all the components in each personality are fully counted, which create the holistic model, where personality, social and cultural-historical aspects are included. Understanding of the personality aspect is found in the approach based on the personality theory, stating that personality has both subsistent and acquired qualities and the feature characterising the identity - the ability to reflect about oneself and qualities. The social aspect is connected with the relationships among individuals in the society, social groups, and also with the socialisation process in the widest sense that can be analysed retrospectively and in the closest perspective in respect of what happens during communication, for example, retelling life-stories. The cultural and historical aspect includes material and intellectual cultural components, which were created as the result of human activities, as well as attitude of people to each other regarding created values, spiritual world, the environment, which could also be created not by human activities, for example, the nature, landscapes. 
Table 2 Table of frequencies for determining the frequency of contents (conceptual) codes denoting identity criteria of the personality aspect

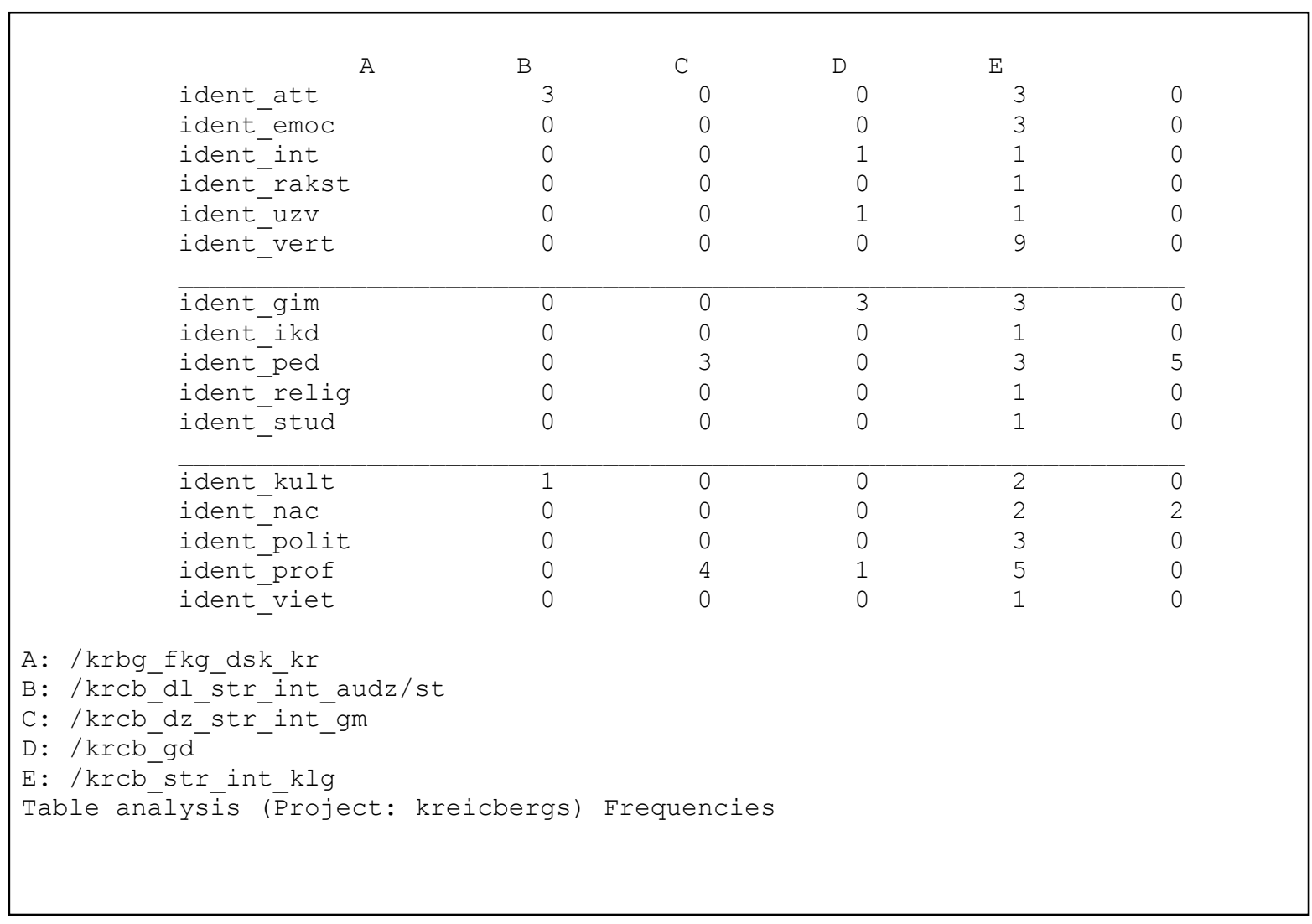

Distribution of mentioned frequencies of various identities by choir members, students/pupils, family members, K. R. Kreicbergs himself and colleagues of K. R. Kreicbergs in relation to the personality, social, cultural and historical aspect provided in the table of meta code frequencies denoting identity aspects testifies that personality aspects of the identity dominate in the statements of K. R. Kreicbergs and choir members; in the opinion of family members he had social aspect of the identity, but colleagues and students outlined the cultural and historical aspect of the identity (see Table 2).

Data of contents analysis testify that respondents mostly identify K. R. Kreicbergs with attitudes, then with interests and to the same extent with behaviour. Contextually there are no contradictions that respondents identify the title person of the monograph K. R. Kreicbergs with values, though it comes out from the values reflected in the K. R. Kreicbergs's self-awareness, which he prioritizes. In the hierarchy of $\mathrm{K}$. R. Kreicbergs's values, the duty is dominant. He critically assesses the popular discourse among the contemporary young people, where morale of rights dominates at the foreground. Different opinions can be explained mostly by upbringing and education in the family and at 
school. Kreicbergs believes that the duty of pupils is to study and the duty of teacher is to bring up and educate. Beside this it is necessary to mention such values as awareness of the fatherland, spirituality, and they are to be inculcated from the birth to feel the mutual humane sincerity, sensitivity, love, trust and fairness.

The social aspect of the identity in its variety opens in the pedagogue and conductor's story about life space, which is childhood, where child's eyes noticed all the daily steps of parents, as well as school time, where selfawareness became more stable and it became clear what means „We" and "Others”. „We" - that is a family, kin, with a certain economic base, so that parents could educate their children, cultivate their fields, live in the large and newly built house. Whereas „Others" in the opinion of a young human, are all those, who in some sense are different from what is seen in the father or relatives' house, who have not had an opportunity or a wish to study; those others are also those, who were in the same community among his mother's relatives, in the church, in the traditionally held events, among neighbours and contemporaries at school. Impressions of childhood and teen-age years appear also in the cognitions accumulated during the next years of life and also affect the process of value crystallisation.

The identity in cultural and historical aspect dominates in narrations of colleagues and pupils/students, and also it is identified in Kreicbergs's expressions. In the self-reflection of K. R. Kreicbergs, which describes the selfdimension of the personality, it is an important component of self-identity. In Kreicbergs's narration there are not any foreign expressions, which testify selfbelonging to ,cultural nation”, ,intelligence”, ,educated layer”, „handled musicality" The same was also marked by colleagues, when describing K. R. Kreicbergs as the conductor of the certain cultural generation period with distinct awareness of responsibility, determinate position and clearly formulated attitude to cultural values, which can be subjective (E. Račevskis, I. Valce, V. Vikmanis, V. Kronbergs). During interviews seemingly little attention to the cultural and historical aspects of the identity was paid by those choir members, which do not approve the absence of cultural and historical components typical to K. R. Kreicbergs's identity. However, the socialisation and self-expression aspects of choir members and the importance of recognition and participation are dominant. The mediate contextual conception is influenced by the presence of cultural and historical aspects. 
Proceedings of the International Scientific Conference. Volume IV, May $27^{\text {th }}-28^{\text {th }}$, 2016. 512-524

Table 3 Table of content (conceptual) code frequencies denoting factors influencing development of identity

\begin{tabular}{|c|c|c|c|c|c|}
\hline & A & B & $\mathrm{C}$ & $\mathrm{D}$ & $\mathrm{E}$ \\
\hline iaif atz & 0 & 0 & 2 & 11 & 5 \\
\hline iaif_izv & 0 & 0 & 0 & 13 & 0 \\
\hline iaif ${ }^{-} l d z d$ & 1 & 6 & 1 & 1 & 0 \\
\hline iaif_uzt & 3 & 1 & 0 & 1 & 0 \\
\hline iaif_dros & 0 & 0 & 3 & 0 & 0 \\
\hline iaif_jb & 0 & 0 & 0 & 14 & 2 \\
\hline \multicolumn{6}{|c|}{$\mathrm{A}:$ / krbg fkg dsk kr } \\
\hline \multicolumn{6}{|c|}{ B: /krcb_dl_str_int_audz_st } \\
\hline \multicolumn{6}{|c|}{ C: /krcb_dz_str_int_gm } \\
\hline \multicolumn{6}{|c|}{$\mathrm{D}:$ /krcb_gd } \\
\hline \multirow{2}{*}{\multicolumn{6}{|c|}{$\mathrm{E}:$ / krcb str int_klg }} \\
\hline & & & & & \\
\hline
\end{tabular}

Different groups of respondents have pointed out various factors, which influence identity development. These are trust for members of the choir, participation for students, safety for family members, ought-being (i.e., moral obligation) for K. R. Kreicbergs, recognition for colleagues, but such factors as recognition, ought-being and choice are among the most often mentioned (see Table 3).

Table 4 Statistical importance of differences when identifying identities in various respondent groups

\begin{tabular}{|c|c|c|c|c|}
\hline $\begin{array}{l}\text { Categories } \\
\text { of identity }\end{array}$ & $\begin{array}{l}\text { Chi-Square } \\
\text { test results }\end{array}$ & $\begin{array}{l}\text { Kruskal - } \\
\text { Wallis H- } \\
\text { test results }\end{array}$ & $\begin{array}{l}\text { The highest } \\
\text { value }\end{array}$ & The lowest value \\
\hline attitude & $\chi^{2}(2)=22.510$ & $\mathrm{p}=0.000$ & $\begin{array}{l}\text { choir members } \\
(\text { Mean } \\
\text { Rank=11.50) }\end{array}$ & $\begin{array}{l}\text { colleagues, pupils, } \\
\text { students, family } \\
\text { members (Mean } \\
\text { Rank=35.50) }\end{array}$ \\
\hline pedagogue's & $\chi^{2}(2)=22.423$ & $\mathrm{p}=0.000$ & $\begin{array}{l}\text { colleagues (Mean } \\
\text { Rank=15.14) }\end{array}$ & $\begin{array}{l}\text { choir members, family } \\
\text { members (Mean } \\
\text { Rank=38.00) }\end{array}$ \\
\hline family & $\chi^{2}(2)=13.760$ & $\mathrm{p}=0.009$ & $\begin{array}{l}\text { family members } \\
(\text { Mean } \\
\text { Rank=19.50) }\end{array}$ & $\begin{array}{l}\text { pupils, students, choir } \\
\text { members, colleagues } \\
\text { (Mean Rank=35.50) }\end{array}$ \\
\hline professional & $\chi^{2}(2)=11.491$ & $\mathrm{p}=0.023$ & $\begin{array}{l}\text { pupils and } \\
\text { students }(\text { Mean } \\
\text { Rank=19.21) }\end{array}$ & $\begin{array}{l}\text { choir members, } \\
\text { colleagues (Mean } \\
\text { Rank=37.50) }\end{array}$ \\
\hline
\end{tabular}


The results of Kruskal-Wallis H-test for quantitative data processing in the SPSS software environment testify that there are statistically maximally important differences among respondent status and such identity categories as attitude and pedagogue's identity: the attitude was more frequently identified by choir members, in comparison to colleagues, family members, pupils and students, who did not mention that, but the pedagogue's identity - by colleagues, in comparison to choir members and family members, who did not mention that. Statistically very important difference is discovered among respondent status and the family identity - this was more frequently identified by family members, in comparison to choir members, colleagues, students and pupils, who did not mention that. Statistically important difference is discovered among respondent status and the professional identity - this was more frequently identified by pupils and students, in comparison to choir members and colleagues who did not mention that (see Table 4).

Table 5 Statistical importance of differences when identifying factors influencing development of identities in various respondent groups

\begin{tabular}{|c|c|c|c|c|}
\hline Factors & $\begin{array}{l}\text { Chi-Square } \\
\text { tests results }\end{array}$ & $\begin{array}{l}\text { Kruskal - } \\
\text { Wallis H-test } \\
\text { results }\end{array}$ & $\begin{array}{l}\text { The highest } \\
\text { value }\end{array}$ & The lowest value \\
\hline trust & $\chi^{2}(2)=27.708$ & $\mathrm{p}=0.000$ & $\begin{array}{l}\text { choir members } \\
(\text { Mean } \\
\text { Rank=11.00) }\end{array}$ & $\begin{array}{l}\text { colleagues (Mean } \\
\text { Rank=35.00) }\end{array}$ \\
\hline participation & $\chi^{2}(2)=35.179$ & $\mathrm{p}=0.000$ & $\begin{array}{l}\text { pupils (Mean } \\
\text { Rank=9.57) }\end{array}$ & $\begin{array}{l}\text { colleagues (Mean } \\
\text { Rank=37.00) }\end{array}$ \\
\hline safety & $\chi^{2}(2)=29.951$ & $\mathrm{p}=0.000$ & $\begin{array}{l}\text { family } \\
\text { members } \\
(\text { Mean } \\
\text { Rank=18.00) }\end{array}$ & $\begin{array}{l}\text { pupils, students, choir } \\
\text { members, family } \\
\text { members (Mean } \\
\text { Rank }=34.00)\end{array}$ \\
\hline recognition & $\chi^{2}(2)=10.716$ & $\mathrm{p}=0.030$ & $\begin{array}{l}\text { colleagues } \\
(\text { Mean } \\
\text { Rank=18.64) }\end{array}$ & $\begin{array}{l}\text { choir members (Mean } \\
\text { Rank=41.50) }\end{array}$ \\
\hline $\begin{array}{l}\text { moral } \\
\text { obligation }\end{array}$ & $\chi^{2}(2)=7.725$ & $\mathrm{p}=0.049$ & $\begin{array}{l}\text { K.R.Kreicbergs } \\
(\text { Mean } \\
\text { Rank=29.30) }\end{array}$ & $\begin{array}{l}\text { colleagues, pupils, } \\
\text { students, family } \\
\text { members (Mean } \\
\text { Rank=40.50) }\end{array}$ \\
\hline choice & $\chi^{2}(2)=9.635$ & $\mathrm{p}=0.047$ & $\begin{array}{l}\text { K.R.Kreicbergs } \\
(\text { Mean } \\
\text { Rank=28.60) }\end{array}$ & $\begin{array}{l}\text { pupils, students, choir } \\
\text { members, family } \\
\text { members (Mean } \\
\text { Rank=39.00) }\end{array}$ \\
\hline
\end{tabular}

The results of Kruskal-Wallis H-test for quantitative data processing in the SPSS software environment testify that there are statistically maximally 
important differences among respondent status and participation, trust and safety: participation was more frequently identified by pupils and students, in comparison to colleagues; trust - by choir members, in comparison to colleagues, but safety - by family members, in comparison to the other respondent groups. Statistically important differences are discovered among respondent status and recognition, moral obligation and choice: recognition was more frequently identified by colleagues, in comparison to choir members, but moral obligation and choice were more frequently mentioned by $\mathrm{K}$. R. Kreicbergs himself, in comparison to the other respondent groups (see Table 5).

In the environment of AQUAD software for qualitative data processing combinations of identity condition implicants are identified:

- $\quad$ in the personality aspect this is influenced by moral obligation in the micro context (1 case);

- $\quad$ in the social aspect - trust and safety in mezzo context ( 1 case);

- in the cultural and historical aspect - participation and recognition in macro context (1 case).

The qualitative data analysis results obtained in the AQUAD software environment approved the results of quantitative data analysis in the SPSS software environment - in the cluster analysis such case groups are defined:

- identity in the personality aspect is influenced by moral obligation and choice in micro context;

- identity in the social aspect is influenced by trust and safety in mezzo context;

- identity in the cultural and historical aspect is influenced by participation and recognition in macro context.

During the research it is obtained how creation of identity is influenced by the environment across the full variety spectrum and complexity, starting from micro and finishing with macro contexts in family and at work, and also in socialisation process touching various social groups.

\section{Conclusions}

The results obtained in the practical research correspond to the theoretical statements, which originally come from the holistic nature of the personality self-identity and social identities in the conceptual statements.

The approbated Model of Teachers Identity and Factors Influencing Development thereof is a successful tool for determination of factors influencing development of personality and pedagogue's identities, which reveals an opportunity of wide application in other researches. 
Looking from the theoretical perspective of the identity, in the subheading of the monograph: „Biographical insights about the excellent cultural and educational professional - conductor, teacher" there is a meaning of the statement included and also the question of the research has been approved, that is testified by the results of the research:

- Pedagogue's professional identities, as well as identification with values are dominant for K. R. Kreicbergs.

- Recognition, moral obligation and choice are the most important factors influencing development of K. R. Kreicbergs's identity.

- Identification of K. R. Kreicbergs with values, interests, emotions, talent, behaviour, convictions, character, attitude and motivation is influenced by moral obligation and choice.

- Formation of the pedagogue, student, family, everyday life and religious identity in K. R. Kreicbergs's life is influenced by trust and safety in the work, study, family and everyday life, and community environment, but formation of professional, national, political, local and cultural identity is influenced by participation and recognition in the educational, ethnic, political, geographical and cultural environment.

- The linkages discovered between identity and the environment testify that the work environment is determinative for development of pedagogue's identity, and also the family environment - for family identity, the study environment - for student identity, the everyday environment - for everyday identity and the community environment - for religious identity, the political environment - for political identity, the ethnical environment - for ethnical identity, the geographical environment - for local identity and the cultural environment - for cultural identity development.

The case study process and the obtained results can be generalised in the local period in the historical, cultural and educational space. Further wider approbation of the research model of factors influencing pedagogue's identity and development thereof in the other cultural space and environment could allow discussions about the universal nature of the theoretical model.

\section{References}

Abrams, L. (2010). Oral History Theory. London \& New Yourk: Routledge.

Beitnere, D. (2003). Pašreference latviě̌u kultūras paradigmā. (20. gadsimta 20.-40. un 90. gadi lìdz mūsdienām). Disertācija socioloğijāa. LU Filozofijas un socioloğijas institūts. Rīga: Rīgas Stradiña universitāte.

Bela-Krūmiṇa, B. (2004). Dzīvesstāsti kā sociāli vēstījumi. Promocijas darba kopsavilkums. Rīga: Latvijas Universitāte. 
Illeris, K. (2014). Transformative Learning and Identity. 3rd edition. London, New York: Routledge.

Knowles, G. J. (1992). Models for understanding pre-service and beginning teachers' biographies: Illustrations from case studies. In I. F. Goodson (Ed.). Studying teachers' lives. London: Routledge, 99-152.

Lieǵeniece, D. (1992). Bērns - pasaulē, pasaule - bērnā. Rīga: Zvaigzne.

Lieǵeniece, D. (2002). Ievads andragoğijā jeb Mācī̌sanās "būt”" pieaugušo vecumā. Rīga: RaKa.

Lieǵeniece, D. (1999). Kopveseluma pieeja audzināšanā. Rīga: RaKa.

Lieğeniece, D (1996). Kopveseluma pieeja 5-7 gadus veca bērna audzināšanā.. Liepāja: LPA.

Lieǵeniece, D. (2013). Kopveseluma pieeja 5-12 gadu vecu bērnu uzvedības izpratnei sociālajā vidē. Holistic Approach to Understanding Behaviour of $5-12$ Year Olds in a Social Environment. Society, Integration, Education. Proceedings of the International Scientifical Conference. Rēzekne: 37-47.

Liepājas Pedagogijas akadēmijas darbinieku dzīvesstāsti. 1. laidiens. (2004). Sast. un red. A. Medveckis. Liepāja: LiePA.

Liepājas Pedagogiijas akadēmijas darbinieku dzīvesstāsti. 2. laidiens. (2006). Sast. un red. A.Medveckis. Liepāja: LiePA.

Liepājas Pedagoǵijas akadēmijas darbinieku dzīvesstāsti. 3. laidiens. (2009). Sast. un red. A. Medveckis. Liepāja: LiePA.

Luhmann, N. (1999). Social System. Stanford: Stanford University Press.

Mārtinsone, K. (1998). Adekvāts pašvērtējums - optimāls pašizjūtas un savas identitātes apzināšanās garants. Personības pašizjūta un identitāte. Rīga: SIA "Mācību apgāds" NT. 27-40.

Medveckis, A. sastād. un redaktors (2007). Liepājas Pedagoǵijas akadēmija (Liepājas Universitāte) Akadēmiskā personāla biogrāfiskais rādītājs. Liepāja: LiePA.

Medveckis, A. (2012). Kārlis Rūdolfs Kreicbergs un vinga laiks. Monogrāfija. Liepāja: Liepājas Universitāte Sociologisko pētījumu centrs.

Medveckis, A. (2016). Pedagoga identitātes refleksija dzīvesdarbībā: pētniecības teorētiskais modelis. (Manuskripts) Liepāja: LiepU Sociologisko pētījumu centrs.

Medveckis, A. (2015). Model of Teachers' Identity Factors in the Biographical Research. Internacional Journal of Multidisciplinary Thougt, CD-ROM. 08(01), 85-98.

Plotnieks, I. (1998). Personības pašizjūta un identitāte, to izpētes iespējas. Personības pašizjūta un identitāte. Rīga: SIA "Mācību apgāds” NT. 9-17.

Strika, E. (2009). Tiesu psihiatriskajā vai kompleksajā tiesu psihologiskajā un psihiatriskajā ekspertīzē nonākǔ̌o likumpārkāpēju personības raksturojums. Promocijas darba kopsavilkums. Rīga: Latvijas Universitātes Pedagogijas un psihologijas fakultātes Psiholoǵijas nodalıa.

Thompson, P. (2000). The voice of the past. Oral history. Oxford: Oxford University Press. 